\title{
Training participation and the role of reciprocal attitudes
}

Citation for published version (APA):

Non, A. (2018). Training participation and the role of reciprocal attitudes. Maastricht University, Graduate School of Business and Economics. GSBE Research Memoranda No. 024 https://doi.org/10.26481/umagsb.2018024

Document status and date:

Published: 13/11/2018

DOI:

10.26481/umagsb.2018024

Document Version:

Publisher's PDF, also known as Version of record

\section{Please check the document version of this publication:}

- A submitted manuscript is the version of the article upon submission and before peer-review. There can be important differences between the submitted version and the official published version of record.

People interested in the research are advised to contact the author for the final version of the publication, or visit the DOI to the publisher's website.

- The final author version and the galley proof are versions of the publication after peer review.

- The final published version features the final layout of the paper including the volume, issue and page numbers.

Link to publication

\footnotetext{
General rights rights.

- You may freely distribute the URL identifying the publication in the public portal. please follow below link for the End User Agreement:

www.umlib.nl/taverne-license

Take down policy

If you believe that this document breaches copyright please contact us at:

repository@maastrichtuniversity.nl

providing details and we will investigate your claim.
}

Copyright and moral rights for the publications made accessible in the public portal are retained by the authors and/or other copyright owners and it is a condition of accessing publications that users recognise and abide by the legal requirements associated with these

- Users may download and print one copy of any publication from the public portal for the purpose of private study or research.

- You may not further distribute the material or use it for any profit-making activity or commercial gain

If the publication is distributed under the terms of Article $25 \mathrm{fa}$ of the Dutch Copyright Act, indicated by the "Taverne" license above, 


\section{Maastricht University}

Arjan Non

Training participation and the role of reciprocal attitudes

RM/18/024

\section{GSBE}

Maastricht University School of Business and Economics

Graduate School of Business and Economics

P.O Box 616

NL- 6200 MD Maastricht

The Netherlands 


\title{
Training participation and the role of reciprocal attitudes
}

\author{
Arjan Non ${ }^{1}$
}

08-11-2018

\begin{abstract}
Using data from the German Socio-Economic Panel (SOEP), I examine the relation between workers' reciprocal attitudes, as measured in 2005 and 2010, and participation in work-related training courses in 2007 and 2013, respectively. Theory predicts that employers find it more profitable to invest in human capital of workers who have positively reciprocal attitudes, because they are more likely to return their employer's kindness with higher effort and/or loyalty. The findings are mixed, depending on the survey year. I find that positively reciprocal workers are more likely to participate in employer-financed training in 2007, in particular when training is general. Also consistent with theoretical expectations, I do not find a relation between workers' reciprocal attitudes and participation in training that is not financed by the employer. However, workers' reciprocal attitudes are not related to training participation in 2013. A possible explanation is that employers use training to induce reciprocal feelings in a slack labour market only.
\end{abstract}

Keywords: Reciprocity, training, SOEP

JEL codes: M53, D91

\footnotetext{
${ }^{1}$ University of Bonn, ROA and CESifo. Email: anon@uni-bonn.de I thank Robert Dur, Bert van Landeghem, Raymond Montizaan, Jens Mohrenweiser, Panu Poutvaara, Jan Sauermann, and Thomas Zwick for their useful comments and suggestions. I also thank participants of the CESifo Area conference Employment and Social Protection 2015, the IAB/ZEW Workshop "Assessing the Impact of Human Resource Management Practices" in Mannheim 2015, POEK 2015 in Vienna, the BIBB workshop on "The Economics of VET" in Bonn, 2015 and ESPE 2016 in Berlin for their useful comments and suggestions.
} 


\section{Introduction}

A skilled and knowledgeable workforce is essential for organizational performance. Employers may therefore benefit from investing in workers' human capital, for instance by supporting workers to participate in formal training programs. However, employers do not always have an incentive to invest, because the profitability of human capital investment depends on workers' behaviour. For example, a well-known theme in the literature on training is the problem of hold-up (Becker, 1962, see also Leuven, 2005). After the employer paid for a worker's training, the worker has an improved bargaining position, as his productivity is higher than before the training. He may exploit this situation by asking for a higher wage, or by moving to a competing firm when the training is general. As another example, the returns to training depend on workers' motivation. Training arguably has a larger effect on productivity when workers exert effort to put the new skills and knowledge into practice. Employers may therefore find it more profitable to invest in some workers than in others, depending on their expected behaviour. Since behaviour is, for given material incentives, affected by relatively stable personality traits and attitudes (Heckman and Kautz, 2012), we would expect that particular traits and attitudes are related to workers' participation in firm-provided training. ${ }^{2}$

In this paper, I study the role of workers' tendency to positively reciprocate, i.e. the tendency to return favours. Employers may find it more profitable to invest in workers with positively reciprocal attitudes. One reason is that, to the extent workers perceive their employer's investment in their human capital as kind, workers with reciprocal preferences will be inclined to return this favour with higher effort and/or higher loyalty. A basic prediction is therefore that workers who are more inclined to reciprocate are more likely to participate in vocational training that is financed by the employer. At the same time, we would not expect that reciprocal workers are more likely to participate in training they finance themselves. Own-financed training clearly does not invoke positively reciprocal feelings, and it is likely that there is some substitution of the source of finance: when employers are more willing to finance training, workers are less likely to finance it themselves. A third prediction is that the relation between positively reciprocal attitudes

\footnotetext{
2 Examples of traits and attitudes that affect training participation are Big-5 personality traits, locus of control (Offerhaus, 2013, Gerards et al. 2014), motivation to learn (Nelen and De Grip, 2009), and time preferences (Fouarge et al., 2013).
} 
and participation in employer-financed training is stronger when the training is general, in the sense that the learned skills are visible and transferable for outside parties, than when it is firm-specific. One reason is that reciprocity can alleviate the hold-up problem that arises when training is general, as argued by Leuven et al. (2005), but does not arise when training is firm-specific. Another reason is that general training is more valuable from the worker's perspective, and therefore more likely to be perceived as kind (Barrett and O'Connell, 2001, p. 659).

I test these predictions using survey data from the German Socio-Economic Panel (SOEP). The 2005 and 2010 waves of the SOEP contain a validated measure of individuals' reciprocal inclination, while retrospective information on training participation is collected in 2008 and 2014. This allows me to relate individuals' reciprocal attitude as measured in 2005 and 2010 to training participation in the year preceding the 2008 and 2014 waves, respectively. The main finding is that individuals with positively reciprocal attitudes are more likely to participate in training in 2007, but I find no relation with training participation in 2013. Positively reciprocal workers are more likely to participate in employer-financed training in 2007. This relation seems stronger when the training is general rather than firm-specific, but this difference is not statistically significant and depends on how general training is measured. At the same time, positively reciprocal workers are not more likely to participate in training they financed themselves, or in training that is only weakly supported by the employer. I do not find any relation between positively reciprocal attitudes and participation in employer-financed training in 2013.

A possible explanation for those diverging findings is inspired by the fact that labour market circumstances in Germany greatly improved after 2007. ${ }^{3}$ Employers may provide training to build gift-exchange relationships only when the labour market is slack. This makes economic sense: employees have a higher valuation of general training when they perceive a substantial risk of becoming unemployed. Although somewhat speculative, more detailed analysis provides support for this explanation. There is no relation between reciprocal attitudes and training in occupations that have relatively good perceived labour

\footnotetext{
${ }^{3}$ For example, unemployment decreased from $8.6 \%$ in 2007 to $5.2 \%$ in 2013 , and the employment rate of $25-59$ years old rose from $78.5 \%$ to $82.4 \%$ (source: Eurostat).
} 
market prospects, neither in 2007 nor in 2013. The relation seems driven by occupations with relatively poor perceived labour market prospects, in particular in 2007.

The paper that is closest related to this study is Leuven et al. (2005). They propose workers' positive reciprocity as a resolution for the hold-up problem, and provide empirical support for this idea using Dutch cross-sectional data. They find a positive relation between workers' reciprocal attitudes and participation in employer-supported training, and no relation when the training is not financially supported by the employer. The main contribution of this study over Leuven et al. (2005) is the richness of the SOEP data. The SOEP has more observations at several points in time, contains validated measures of reciprocity as well as potentially confounding personality traits, ${ }^{4}$ and allows for distinguishing between firm-specific and general training.

A second study addressing this topic is Gerards et al. (2014). Using data from a large company in the Netherlands, they investigate the relation between workers' reciprocal attitudes and the use of training vouchers provided by their employer. ${ }^{5}$ They find that positively reciprocal workers do not use their vouchers more often, while negatively reciprocal workers are less likely to use their vouchers. They find no relation between reciprocity and non-voucher training. A possible interpretation is that workers view the provision of training vouchers negatively, as the voucher scheme was introduced in the midst of the global financial crisis and the company had just gone through a number of large-scale reorganizations. Their findings might therefore be specific for the particular organization and time period studied.

Two related papers provide evidence that workers positively reciprocate employerfinanced training. Sauermann (2015) combines data from a randomized field experiment conducted in a call-centre with survey data measuring workers' reciprocal attitude. He concludes that workers with positively reciprocal attitudes show a larger productivity increase after training. Montizaan et al. (2015) point towards a different reciprocation

\footnotetext{
${ }^{4}$ Englmaier et al. (2016, p. 525) discuss recent empirical evidence on the relation between personality traits -as often measured in personality tests- and reciprocal attitudes.

${ }^{5}$ Becker et al. (2013) also investigate reciprocal reactions towards the provision of training vouchers, but not in an employment relationship. Training vouchers are provided to survey participants as a reward for their survey participation, which is reciprocated with future participation by those who redeem their voucher.
} 
mechanism. They report a positive association between having access to employerprovided training and individuals' expected retirement age. Interestingly, it is the firm's provision of training opportunities rather than individuals' actual training participation that drives this relationship, and this relation is concentrated among individuals who have a strong reciprocal orientation. This suggests that workers reciprocate generous training policies by postponing retirement. ${ }^{6}$ My paper complements those studies by addressing the question whether reciprocal individuals are generally more likely to participate in employer-financed training, as would be expected when employers correctly predict workers' reciprocal tendencies.

This paper also contributes to a broader literature on the importance of reciprocal behaviors in employment relationships. The literature has mainly focused on the question whether paying generous wages motivates workers to exert more effort, using both lab (see Fehr and Gächter, 2000) and field experiments (see e.g. Gneezy and List, 2006, Hennig-Schmidt et al., 2010, Kube et al., 2012, and Esteves-Sorenson, 2017). However, as pointed out theoretically by Dur (2009), paying a generous salary may not be the most efficient way to induce reciprocal feelings. Instead, employers may find it more efficient to give managerial attention to their workers, which may include provision of training opportunities. $^{7}$ This study is one of the few to explore the empirical evidence on this particular channel. Interestingly, the finding that the relation between reciprocal attitudes and training participation seems to depend on perceptions of the labour market across occupations is in the spirit of Dur's (2009) model: depending on the environment, employers choose the most efficient instruments to induce reciprocal feelings.

The paper proceeds as follows. In the next section, I derive testable hypotheses and discuss the underlying assumptions. In section 3 , I discuss the data and define various

\footnotetext{
${ }^{6}$ A number of other papers provide suggestive evidence that training participation induces reciprocal reactions. Kampkötter and Marggraf (2012) show that absenteeism and turnover rates are lower after training participation. Likewise, studies in Organizational Behaviour report a positive association between a positive human resource development climate (HRDC) and measures of employee effort and loyalty, such as organizational citizenship behaviour (OCB) and turnover intentions (Mittal et al., 2016, Benjamin, 2012, Mullen et al., 2006, and Bartlett, 2015).

7 Based on a survey paper by Cropanzano and Mitchell (2005, p. 881), Dur (2009) defines managerial attention as socioemotional resources that "address one's social and esteem needs (and are often symbolic and particularistic)." Cropanzano and Mitchell (2005, p. 881) continue by saying: "Moreover, socioemotional outcomes send the message that a person is valued and/or treated with dignity". Offering participation in carefully selected training programs seems to be a good example of the latter.
} 
types of training. In section 4 , I present the estimation results. Section 5 discusses additional analyses to interpret the results. Section 6 concludes.

\section{Hypotheses}

\subsection{Theoretical framework}

Reciprocity means that individuals tend to respond in kind: they return favors, but take revenge for wrongdoings. The former is referred to as positive reciprocity, while the latter is referred to as negative reciprocity. A key assumption in this study is that individuals differ in the extent to which they feel inclined to reciprocate, and that this inclination can be viewed as a stable trait or preference. ${ }^{8}$ A second important assumption is that employers have a generally accurate assessment of workers' tendency to reciprocate, on which they base their decision to offer training. This is not such a strong assumption as it may seem at first sight. First, Stirrat and Perrett (2010), Little et al. (2013), Centorrino et al. (2015), and De Neys et al. (2015) show that experimental subjects are able to predict reciprocal behaviour in a trust game on the basis of pictures and short videos of the trustees. Those findings suggest that employers, who interact with their employees on a daily basis, are well able to predict employees' behaviour. ${ }^{9}$ Second, there is no need to assume that employers know the reciprocal attitude of each individual worker and offer training to workers with strong positively reciprocal preferences only. Employers can base their training policies on the median or average reciprocal attitude in the organization. They do not even need to observe those attitudes: when employees selfselect into workplaces based on their reciprocal attitudes or correlated characteristics, employers can rely on their past experiences to decide on training policies. This mechanism is reinforced by the use of personality tests to screen employees on traits associated with reciprocal behaviour, as argued by Englmaier et al. (2016).

\footnotetext{
${ }^{8}$ See Dohmen et al. (2009) and Falk et al. (2018) for a discussion of predictive validity and (global) heterogeneity in reciprocal preferences. See Golsteyn and Schildberg-Hörisch (2017) for a general discussion on the stability of personality traits and preferences.

${ }^{9}$ Finan and Schechter (2012) provide field evidence from a different setting. They show that community leaders in Paraguay accurately predict reciprocal preferences of villagers, and specifically target reciprocal individuals when buying votes for politicians.
} 
Economic theory provides several reasons why employers are more likely to train positively reciprocal workers. When workers perceive the employer's investment in their human capital as kind, they reciprocate with behaviour that benefits the employer. Leuven et al. (2005) emphasize one particular reaction, namely that reciprocal workers do not exploit their improved bargaining position (e.g. by asking for a higher wage). However, it is easy to think of several other options workers have to reciprocate, such as being more loyal or exerting more effort. It is therefore more profitable to train workers who have a strong tendency to reciprocate favours. This leads to the first prediction:

H1: workers with positively reciprocal attitudes are more likely to participate in employer-financed training.

Following the reasoning above, there is no reason to expect that workers with reciprocal preferences are more likely to participate in training they financed themselves. Clearly, a worker can always decide to participate in a training course when his employer is not willing to sponsor the training, but such training participation cannot be perceived as a gift and hence does not invoke positively reciprocal feelings. Moreover, it is likely that there is substitution of the source of finance: when employers are more willing to finance positively reciprocal workers' training, it must mean that they participate in training more often, or that they are less likely to finance training themselves. It is a priori unclear to what extent employer-financed training crowds out worker-financed training, but we can conservatively predict that:

$\mathrm{H} 2$ : workers with positively reciprocal attitudes are not more likely to participate in worker-financed training.

In principle, it is possible that employer's higher willingness to invest in reciprocal workers merely implies a substitution in who finances training. Full substitution, however, seems unlikely. As we shall see, the data show that many workers do not participate in training at all, while own-financed training is relatively rare. It is therefore plausible that at least some of the additional employer-financed training induces workers to train who would not have done so otherwise. Hence, a third prediction is:

H3: workers with positively reciprocal attitudes are more likely to participate in training. 
An important distinction is between general and firm-specific training. A training is general when two conditions are met. First, the acquired skills must be transferable, in the sense that they are also valuable in other organizations. Second, the training must be visible: the worker should be able to prove his participation and credibly communicate the value of the training to other employers. General training therefore leads to the holdup problem described in the introduction: trained workers have an improved bargaining position which they may exploit. As formally shown by Leuven et al. (2005), positively reciprocal workers are less inclined to do so, which makes it more attractive to train them as compared to self-interested workers. This argument does not apply to firm-specific training, since workers cannot credibly threaten to change employer in wage renegotiations. Workers' reciprocal attitudes are therefore less relevant when training is firm-specific:

H4: The relation between workers' positively reciprocal attitudes and participation in employer-financed training is stronger when training is general than when it is firmspecific.

A second motivation for this hypothesis is that general training may be perceived as more kind than firm-specific training when workers realize that the former is more valuable than the latter (Barrett and O'Connell, 2001, p. 659). Employers may therefore expect that positively reciprocal workers feel more inclined to reciprocate general training than firm-specific training. ${ }^{10}$

\subsection{Alternative theories}

The key assumption in the theoretical framework outlined above is that workers perceive their employer's training proposals as friendly gifts that deserve to be reciprocated. There are arguably situations where this assumption is not applicable. For instance, workers may think that the training mainly benefits their employer. However, there are alternative theories that yield similar predictions but do not depend on this assumption. First, when training provision does not evoke reciprocal feelings, employers

\footnotetext{
${ }^{10}$ To be more precise, the assumption is that workers' reciprocal reaction is increasing in the perceived value of the gift, and that workers with reciprocal preferences are more sensitive to the value of the gift. These assumptions hold in a simple model with two types, reciprocal and purely self-interested, but need not be true more generally.
} 
may still find it more profitable to train reciprocal workers. The reason is that when employers establish gift-exchange relationships using other means of exchange (e.g. generous wages, informal recognition), reciprocal workers exert more effort than nonreciprocal workers and are more loyal. Training reciprocal workers is therefore more profitable, and in particular when the returns to training are increasing in effort.

Second, it is important to distinguish between employers' training policies and workers' decision to participate. Not all workers are motivated to participate in training (Fouarge et al., 2013), and workers may decide not to exploit the training opportunities they are offered. Training participation can therefore also be seen as an expression of employee effort rather than as a gift from the employer. In this view, reciprocal workers are more willing to participate in training to return favours they received from their employer, provided employers establish gift-exchange relationships via other means. This view reverses the role of training in the gift-exchange relationship, and is common in the literature on Organizational Citizenship Behaviour (OCB). OCB refers to behaviours that benefit the organization but are not contractually enforced. Feelings of reciprocity are typically seen as an important driver of OCB: "For example, employees who receive personal support from their leaders may wish to reciprocate by expending extra effort in the form of citizenship behaviours to help the leader" (Podsakoff et al., 2000, p. 552, see also Eisenberger et al., 2001, for similar remarks). George and Jones (1997) identify selfdevelopment as a key dimension of OCB. ${ }^{11}$ An attractive feature of this explanation is that workers do not need to perceive training as a gift. The empirical predictions are similar, as reciprocal workers self-select into training, but less specific for different types of training. ${ }^{12}$

\subsection{Negative reciprocity}

\footnotetext{
${ }^{11}$ In the words of Podsakoff et al. (2000, p. 525) in their review of the literature on OCB: Self-development includes voluntary behaviours employees engage in to improve their knowledge, skills, and abilities. According to George and Jones (1997: 155) this might include "seeking out and taking advantage of advanced training courses, keeping abreast of the latest developments in one's field and area, or even learning a new set of skills so as to expand the range of one's contributions to an organization."

12 Possibly, reciprocal workers reciprocate by participating in courses that are not fully financed by the employer, or in courses that are firm-specific. Note, however, that it is unlikely that we observe the former relationship empirically, since employers who are not willing to finance training are also unlikely to establish gift-exchange relationships. Unfortunately, the data do not allow me to disentangle the roles of employers and workers.
} 
The theoretical framework concentrates on positive reciprocity (i.e. the tendency to return favors), while reciprocity can also be negative (i.e. the tendency to take revenge for wrongdoings). It is natural to concentrate on positive reciprocity, since employers' training provision is valuable for the worker and therefore most likely perceived as kind. However, it is also possible to speculate about how negative reciprocity affects training participation. Employers may have good reasons not to train negatively reciprocal workers. They may expect that negatively reciprocal workers are more likely to become demotivated as a result of some labour conflict. This is of course always costly, but assuming motivation and skills (training) are complements, it is particularly costly when the worker received training. Moreover, negatively reciprocal workers may decline an offer to participate in training when labour relations are tense, if they believe that by doing so they harm their employer (as argued by Gerards et al., 2014). Based on this reasoning, we would expect that negatively reciprocal workers are less likely to participate in training. However, it is also possible to come up with opposite predictions. As negatively reciprocal behaviour is potentially very costly, employers may want to prevent such behaviour at any cost, and treat workers with negatively reciprocal attitudes more generously. It is therefore not possible to come up with specific predictions. ${ }^{13}$ In the analyses, I use negative reciprocity as control variable, and discuss the empirical relationship with training participation.

\section{Data description}

\subsection{Reciprocity}

The data source is the German Socio-Economic Panel (SOEP), in particular the waves 2005 and 2008 and the waves 2010 and 2014. Data are collected on the individual level and cannot be linked to information on the level of the organization. The 2005 and 2010 waves of the SOEP contain individual measures of reciprocal orientation, while the 2008 and 2014 waves contain information on participation in training. Positively

\footnotetext{
${ }^{13}$ Another reason is that employers may very well use other policies to prevent workers from experiencing negatively reciprocal feelings. When employers believe those policies are effective, there is no reason to expect a relation between workers' negatively reciprocal attitudes and training participation.
} 
reciprocal attitudes are measured by the extent of agreement with three statements, expressed on a scale of 1-7:

1. "If someone does me a favor, I am prepared to return it",

2. "I go out of my way to help somebody who has been kind to me before",

3. "I am ready to undergo personal costs to help somebody who helped me before"

I use individuals' average score on those statements as measure of their reciprocal tendency. Based on this score, I distinguish between three equally-sized groups (low, medium, high) to allow for non-linear effects in the analyses. Perugini et al. (2003) and Falk et al. (2016) validate this measure, while Dohmen et al. (2009) and Falk et al. (2018) discuss the distribution of reciprocal preferences and their correlates in Germany and across the globe, respectively. Negative reciprocity is measured using similar statements, specifically: ${ }^{14}$

1. "If somebody puts me in a difficult position, I will do the same to him/her"

2. "If somebody offends me, I will offend him/her back"

3. "If I suffer a serious wrong, I will take revenge as soon as possible, no matter what the cost"

Although the effect of negative reciprocity on training participation is not the main question of this study, it is interesting to observe the empirical relationship. ${ }^{15}$ I relate reciprocal attitudes as measured in 2005 (2010) to training participation in 2007 (2013), respectively. Note that individuals express their reciprocal preferences before the time period over which training participation is measured, which reduces concerns of reverse causality.

\subsection{Training}

\footnotetext{
14 In 2010, additional questions were asked to measure negative reciprocity, such as: "I get over it relatively quickly when someone hurts my feelings" and "When somebody has wronged me I often think about it for quite a while". I do not include those additional indicators in the measure of negative reciprocity to maintain comparability.

${ }^{15}$ From an ex-ante perspective, it is also important to include negative reciprocity as a control variable. As it turns out, the correlation between positive and negative reciprocity is essentially zero, which rules out multicollinearity concerns.
} 
The 2008 and 2014 waves of the SOEP include information on individuals' training participation, but different questions were asked in each wave. The main difference is that in 2008, subjects were asked to provide information on three courses they followed during the last three years, while in 2014 subjects were asked to provide information on the most important course they took in the preceding year. Another important difference is that different information on each training course is collected. Both waves inquire about who financed the training (in terms of time and money), but information on whether the training is general is collected in 2008 only. General training requires that the worker can prove his participation to other employers and that the acquired skills are sufficiently transferable. The 2008 wave of the SOEP collects this information by asking individuals whether they received a "participation certificate which they would include in job applications in the future", and how they assess "to what extent the newly acquired skills would be useful in a new job in a different company".

To make the analyses of the 2008 and 2014 waves comparable, I confine the analysis of the 2008 wave to the most recent training completed since 01-01-2007. ${ }^{16}$ Based on who financed the course, I define the following mutually exclusive categories of training:

1. Worker-financed training: the employer does not contribute financially, and the course took place outside working hours.

2. Employer-supported training: the employer either contributes financially, or allows the course to take place at least partially during work time, but does not do both.

3. Employer-financed training: the employer pays all of the direct training costs, and allows the course to take place at least partially during work time. ${ }^{17}$

\footnotetext{
${ }^{16} \mid$ refer to training participation after 01-01-2007 as training in 2007, although this includes training participation during the first months of 2008 as well. Likewise, I refer to training as measured in the 2014 wave as training participation in 2013. Although the question asks for training participation during the preceding year, it is not clear whether respondents interpret this as the calendar year or the 12 months preceding the survey. The descriptive statistics show that the rate of training participation is comparable in both waves. Including training courses that took place before 2007 does not affect the main results.

${ }^{17}$ In 2008, individuals were not asked whether the employer paid all (or part) of the costs. Rather, individuals indicate whether they contributed themselves, and whether they received financial support from their employer. It is reasonable to assume that when a worker did not pay anything and received financial support from his employer, all of the direct costs are paid for by the employer.
} 
It is also important to distinguish between general and firm-specific training. Therefore, I further decompose employer-financed training in 2007 by the extent to which the training is general:

1. Firm-specific training: the training does not come with a certificate, and the worker deems the newly acquired skills "to a limited extent" or "not at all" useful in a new job in a different company.

2. Visible or transferable training: the training either comes with a certificate, or the worker considers the newly acquired skills "to a large extent" or "completely" useful in a new job or a different company (but not both).

3. General training: the training comes with a certificate, and the worker deems the newly acquired skills "to a large extent" or "completely" useful in a new job or a different company.

\subsection{Descriptive statistics}

Table 1 provides an overview of the (relative) frequency of the different types of training in the estimation sample. Approximately one third of workers participated in a training course, both in 2007 and 2013. In most cases, employers pay for the direct costs of training and allow the training to take place during work time. Workers bear the full costs of training in roughly one out of ten cases only. Although the rank-order distribution of different types of training is identical in 2007 and 2013, it seems that employers' willingness to finance training has increased over time. In 2007 , only $61 \%$ of trainings were financed by the employer, while six years later 75\% was classified as such. Most employer-financed training courses in 2007 are at least partly general, while firm-specific training is rare (only $12 \%)^{18}$

The estimation sample consists of all individuals who have a regular paid job. I exclude trainees, self-employed, farmers, military, students, and job-creation measure jobs. I also exclude individuals who switched jobs during the period training participation is measured. The reason is that reciprocal attitudes can be expected to be less relevant for this group of workers. Firstly, because trainings offered to those workers are most likely

\footnotetext{
18 The classification of training as general or firm-specific is not significantly different (at the $10 \%$ level) when training is not financed by the employer.
} 
introductory trainings required to do the job, and are therefore offered regardless of reciprocal attitude. ${ }^{19}$ Secondly, because it may take time for employers to learn about workers' reciprocal attitudes and to build gift-exchange relationships. It should be noted that, despite those concerns, the results are robust to the inclusion of job switchers. The exact number of individuals included in the analyses is lower than the numbers reported in Table 1, because not all individuals report information on all control variables. In each estimation table, I ensure that the sample is held constant when adding control variables.

\section{Analysis and Results}

\subsection{Main analysis}

The analysis proceeds as follows. First, I examine whether positively reciprocal workers are generally more likely to participate in training (H3). Then, I take a closer look at this relation by distinguishing between different types of training $(\mathrm{H} 1, \mathrm{H} 2$, and H4). Section 4.2 explores the robustness of the results and their interpretation.

\subsubsection{Training participation}

To examine the relation between workers' reciprocal attitude and their training participation, I estimate probit models where the dependent variable is 1 if the worker participated in training during the last year and 0 otherwise. Table 2 shows the estimation results of different model specifications by survey wave. All specifications control for demographic characteristics, month of interview, and personality characteristics. ${ }^{20}$ Columns 1 to 3 report the estimated average marginal effects for 2007, while columns 4 to 6 report the same relations for 2013 .

The results in column 1 show that positively reciprocal workers (as measured in 2005) are more likely to participate in training over the course of 2007: workers who have

\footnotetext{
${ }^{19}$ Roughly $20 \%$ of job switchers who participated in training indicate that the purpose of the most recent training was an introduction to a new job, against only $3 \%$ in the estimation sample. This number is low in absolute sense, but other training purposes can also be seen as necessary training for a new job, such as "qualification for professional advancement" when the new job implies a promotion.

${ }^{20}$ Demographic characteristics include: gender, age, age squared, tenure, tenure squared, contractual hours, temporary contract, number of children, having a partner, whether the individual ever experienced more than 6 months of unemployment, and nationality. Personality characteristics are: Big-5 personality traits, risk and time preferences, and trust.
} 
medium or highly reciprocal attitudes have a 3.6 percentage points higher probability of participating in training than workers at the bottom of the preference distribution. In column 2, I add dummies for education (8 categories) and occupational status (13 categories plus an indicator for civil servant). The estimated model reported in column 3 additionally controls for firm characteristics: industry ( 7 categories), firm size (6 categories), and workplace location (dummy for location in former DDR). The inclusion of additional controls hardly affects the estimated effect of positively reciprocal attitudes: the tertile most reciprocal workers are roughly 4 percentage points more likely to participate in training than the bottom tertile. Negatively reciprocal workers are less likely to participate in training, but this relation vanishes once controlling for education and occupational status.

Similar analyses on training participation in 2013 paint a different picture. There is no statistically significant relation between positively reciprocal attitudes (as measured in 2010) and training participation in 2013. It is unlikely that this is an artefact of the smaller sample size: the point estimates are close to zero, while the standard errors are of the same magnitude as in 2007 . The estimated effects of negative reciprocity follow the same pattern as in 2007: there is no relation after controlling for education and occupational status.

\subsubsection{Source of finance}

As discussed in the previous section, we would expect that the relation between workers' reciprocal attitudes and training participation strongly depends on how the training is financed. I distinguish between four possible training outcomes: no training participation, participation in worker-financed training, participation in employersupported training, and participation in employer-financed training. To investigate how individuals' reciprocal attitudes influence the probability on each outcome, I estimate a multinomial logit model controlling for demographic characteristics, personality traits, and education. ${ }^{21}$ Table 3 reports the estimated average marginal effects. Coefficients can

\footnotetext{
${ }^{21}$ In all multinomial logit models reported in the paper, I include the same control variables. Education is controlled for by including a dummy for obtaining a degree in tertiary education. The estimated coefficients of positive reciprocity remain similar when controlling more extensively for education, occupational status and workplace location. Unfortunately, it is not possible to include those controls in all analyses due to the limited sample size in some of them.
} 
therefore be interpreted as the average change in probability expressed in percentage points. $^{22}$

The results in columns 1 to 4 of Table 3 show that reciprocal workers' higher training participation is entirely driven by training that is financed by the employer. Workers who belong to the top tertile of the positive reciprocity distribution are almost five percentage points more likely to participate in employer-financed training as compared to the bottom tertile. At the same time, they are not more likely to participate in training that they fully or partially financed themselves. The difference in odds ratios between employerfinanced and worker-financed training is also statistically significant at the one percent level. This finding is consistent with the idea that employers find it more profitable to train workers with positively reciprocal attitudes. As for negative reciprocity, it seems that employers are somewhat reluctant to invest in workers with negatively reciprocal attitudes. Workers with strong negatively reciprocal attitudes are 3.6 percent less likely to participate in employer-financed training. Unreported analyses show, however, that this relation becomes marginally significant $(\mathrm{p}=0.14)$ when controlling more extensively for education and for occupational status.

The estimation results for training participation in 2013 are reported in columns 5-8 of Table 3. Although the results in Table 2 show that positively reciprocal workers are not more likely to participate in training, it could be that there is substitution in who finances the training. The empirical evidence does not support this possibility. Positively reciprocal workers are not more likely to participate in employer-financed training. The estimated average marginal effects are very close to zero and far from statistically significant. This does not change when different training categories are combined into one, for instance by pooling employer-supported and employer-financed training. So, I find no evidence for a relationship between positively reciprocal attitudes and participation in training in 2013, regardless of who financed this training. The pattern for negative reciprocity is the same as in 2007: a negative relation which is sensitive to controlling for education.

\footnotetext{
${ }^{22}$ Note that since the four outcome categories are mutually exclusive, a higher probability on one outcome implies a lower probability on another outcome, so that the estimated coefficients sum to zero over the four categories.
} 


\subsubsection{Visibility and transferability of training}

Next, I investigate the importance of the extent to which the training is general. I extend the multinomial logit model by decomposing employer-financed training into three categories: firm-specific, visible or transferable, and general. The estimation results are reported in Table 4 , in particular columns 4 to 6 . The results suggest that the relation between reciprocal attitudes and participation in employer-financed training is mainly driven by training that is at least to some degree general. Workers who are in the top tertile of the positive reciprocity distribution are 2.3 percentage points more likely to participate in employer-financed training that is general than workers who belong to the bottom tertile (see column 6). At the same time, they are not significantly more likely to participate in employer-financed training that is firm-specific. The estimated effect, reported in column 4, is very close to zero. The difference between firm-specific and general employer-financed training expressed in odds ratios is not statistically significant $(p=0.19)$, however. This suggests that, although the point estimates are consistent with hypothesis H4, we should be careful not to overinterpret this result.

\subsection{Robustness checks}

This section assesses the robustness of the findings reported above. I first examine the robustness of the findings for alternative definitions of firm-specific or general training. Next, I investigate the issue of reverse causality.

The extent to which a training course is general is defined by the combination of workers' subjective assessment of the value of the training in other firms, and whether the training comes with a certificate. One could be worried that the results are sensitive to this definition. Therefore, I redid the analyses using other definitions of general training. First, I investigate the importance of each of the two elements in the definition of general training: visibility and transferability. The results (unreported) are the same, regardless whether I use the provision of a certificate or the worker's subjective assessment to classify training as general.

An alternative approach to define training as general is to distinguish between institutions that provide the training. It is clear that training is visible and transferable 
when it is provided by a formal educational institution or professional organization, while training provided by the employer or other institutions is arguably more specific. The estimation results using this classification method are reported in Table A1 in the appendix. ${ }^{23}$ Positively reciprocal workers are significantly more likely to participate in employer-financed training that is general, while the same is true for trainings provided by the company or other institutions. Although this result is not inconsistent with $\mathrm{H} 4$, it suggests that transferability and visibility are not crucially important.

All analyses above assume that, to the extent the observed correlations have a causal interpretation, the direction of causality goes from reciprocal preferences to training participation. This seems a reasonable assumption, as reciprocal preferences are measured at least 1.5 years before training participation. However, reverse causality is still possible if firms' training policies are serially correlated over time. To examine this issue in more detail, I control for participation in training in the previous survey wave that contains information on training. Specifically, I control for having participated in training financed by the employer, supported by the employer, or financed by the worker as measured in 2004 and 2008. The estimation results are reported in Table A2 in the appendix. The estimated coefficients are hardly affected by the inclusion of previous training participation. Reverse causality is therefore not a likely explanation for the observed correlations.

\section{Why do findings differ between 2007 and 2013?}

\subsection{Possible explanations}

The findings reported above suggest that training participation in 2007 is related to positive reciprocity in ways largely consistent with theoretical expectations, but no such relationship can be found in 2013. How to explain those diverging findings? In this section, I investigate three possible explanations.

\footnotetext{
${ }^{23}$ Using this definition, $24 \%$ of employer-financed trainings are classified as general, as compared to $50 \%$ in the original definition.
} 
As a starting point, it is instructive to exploit the panel dimension of the data to conduct the analyses on the exact same individuals in both survey years. This rules out that findings diverge because of differences in sample composition or in sample size. ${ }^{24}$ Because of the loss of observations (2073 individuals remaining), it is not possible to repeat the analysis with the detailed distinction between training categories as in the main analysis. I therefore distinguish between: a) no training participation, b) training that is worker financed or partially financed by the employer, c) training that is fully financed by the employer. The results of this analysis are shown in Table 5 . The results are consistent with those of the main analysis: the tertile most positively reciprocal workers are significantly more likely to participate in employer-financed training in 2007, but not in 2013. The diverging findings can therefore not simply be attributed to selection of a different sample.

A second explanation is that the sample has aged over time. There are several reasons why the relation between reciprocity and training could be moderated by age and/or labour market experience. For example, older workers may have a more difficult labour market position, which makes it less likely that they exploit an improved bargaining position. Reciprocal attitudes may be irrelevant in such a case. ${ }^{25}$ To address this concern, I split the original sample into three age categories: below 40 years, between 40 and 50 years, between 50 and 65 years. The results of this analysis are reported in Table A3. No clear pattern emerges. If anything, the relation weakens with age: positive reciprocity is not significantly related to employer-financed training participation in 2007 among workers aged above 50. However, unreported analyses show that the interactions between positive reciprocity and the three age groups are far from statistically significant for the average person. Moreover, as can be seen from Table A3, positive reciprocity is not significantly related to employer-financed training participation in 2013 in any of the age categories. It is therefore not plausible that panel ageing is confounding the analysis.

\footnotetext{
${ }^{24}$ Although the sample is kept constant, the same individuals do not necessarily have the same employer six years later: roughly $13 \%$ switched employer. The results are robust to their exclusion from the sample.

${ }^{25}$ Another example is that the marginal impact of training on workers' productivity may be lower for more experienced workers, so that their bargaining position hardly improves. Zwick (2015) shows that, indeed, older workers benefit less from training. An example why the importance of reciprocity could also be increasing with age is that older workers have higher valuation of training, as employers are generally less inclined to invest in older workers (Bassanini et al., 2007).
} 
A natural explanation why the findings differ between both survey waves is that the circumstances have changed. In 2013, despite a global economic crisis, labour market prospects in Germany were much better than in 2007. According to Eurostat statistics, average unemployment among 20-64 years old dropped from 8.6\% in 2007 to $5.2 \%$ in 2013, while the employment rate of 25-59 years old rose by 3.9 percentage points over the same time period. To examine the role of labour market circumstances in more detail, I split the sample based on occupational differences in perceived labour market prospects. Perceptions of labour market prospects are arguably more relevant than objective conditions, because the perceptions drive behaviour. They are measured with the following question: "If you were currently looking for a new job: Is it or would it be easy, difficult, or almost impossible to find an appropriate position?" I take the average response by occupation on the ISCO 2-digit level and by survey year as indicator of perceived labour market conditions in a particular occupation. ${ }^{26}$

I redo the analysis for occupations with relatively good and bad perceived labour market conditions. The results are reported in Table 6 . The upper panel shows estimation results for occupations with relatively good perceived labour market prospects, the lower panel for occupations with relatively bad perceived labour market prospects. The cut-off point is the median. It is clear that the positive relation between positively reciprocal attitudes and participation in employer-financed training in 2007 is mainly driven by occupations with poor perceived labour market prospects. The estimated average marginal effects are statistically significant at the one percent level and more than twice as large as in occupations with good perceived labour market prospects. The differences between occupations with good and bad perceived labour market prospects, however, are not generally statistically significant. A similar pattern can be observed in 2013, although only the intermediate tertile and not the top tertile of positively reciprocal workers is significantly more likely to participate in employer-financed training. Taken together, although the data do not allow for drawing strong conclusions, the pattern is consistent

\footnotetext{
${ }^{26}$ It is reassuring that the responses mirror the overall macroeconomic development outlined above: individuals are significantly more positive about their chances of finding an appropriate job in 2013 than in 2007 . Specifically, in 2007 only $15 \%$ of the estimation sample thought that it would be easy to find a comparable job, compared to $23 \%$ in 2013.
} 
with the notion that the relation between reciprocal preferences and training participation depends on labour market circumstances.

\subsection{Why do perceived labour market circumstances matter?}

The analysis above raises the question why perceived labour market circumstances matter. The most plausible interpretation is that training is viewed as a more valuable gift in a slack labour market, while the opportunity costs of providing it are lower. Training is therefore a relatively efficient tool to induce feelings of reciprocity (Dur, 2009). ${ }^{27}$ To put this interpretation into context, it is instructive to investigate the relation between individuals' reciprocal attitudes and other labour market outcomes. I therefore relate reciprocal attitudes to hours worked, job satisfaction, and income over the time period 2005-2014. Estimation results are reported in Table A4.

Consistent with the gift-exchange hypothesis, I find that positively reciprocal workers report working more hours relative to their contractual hours. Unreported estimations also show that if they work overtime, it is less likely to be compensated. ${ }^{28}$ This is consistent with the hypothesis that positively reciprocal workers exert more effort. Moreover, positively reciprocal workers consistently report higher job satisfaction. This is not because they receive higher wages: positively reciprocal attitudes are only positively related to income in 2006 and 2008. From 2009-2014, the estimated effect on income is essentially zero and not even close to statistically significant. This suggests that the positive association between reciprocal attitudes and income is context-dependent as well. ${ }^{29}$ The overall picture that arises is that employers consistently manage to build giftexchange relationships with reciprocal workers: they work harder yet are more satisfied. However, the analysis also confirms the idea that employers' means of exchange are not

\footnotetext{
27 An alternative interpretation for why labour market circumstances matter is that hold-up problems become so acute in a tight labour market that employers no longer dare to rely on reciprocity. Although intuitive, it is questionable to what extent hold-up problems drive the relation between reciprocity and training. In their review of the literature, Bassanini et al. (2007) point out that employers are generally willing to pay for worker's training. The data used in this study confirm this finding. Recent evidence also suggests that trained workers tend to stay longer with their employer (Dietz and Zwick, 2016), and that voucher-induced training does not lead to higher job mobility (Hidalgo et al., 2014) and wages (Schwerdt et al., 2012, Görlitz and Tamm, 2016).

${ }^{28}$ Zheng (2017) shows that reciprocal workers are more likely to work uncompensated overtime the more their wage exceeds their reference wage. She also finds that reciprocal workers report higher job satisfaction, although this does not depend on their relative earnings.

${ }^{29}$ See Dohmen et al. (2009) for evidence on this relation using the waves 2005, 2006, and 2007.
} 
necessarily monetary or material, and also suggests that the means of exchange are less tangible in times of low unemployment.

\section{Concluding Remarks}

Theory predicts that employers are more willing to invest in training of positively reciprocal workers. To the extent that a training offer is perceived as kind, reciprocal workers will be inclined to return their employer's kindness with higher effort and loyalty. This holds in particular for general training, because general training is more valuable and therefore more likely to induce feelings of reciprocity.

To provide empirical evidence on those predictions, I use data from the German Socio-Economic Panel (GSOEP) to relate reciprocal attitudes, as measured in 2005 and 2010, to training participation in 2007 and 2013, respectively. Consistent with theoretical expectations, I find that workers with a strong positively reciprocal orientation are more likely to participate in training. This is driven by a higher probability of participating in employer-financed training: reciprocal workers are not more likely to participate in training that is not financed by their employer. The relation between reciprocal attitudes and employer-financed training seems stronger when training is general than when it is firm-specific. However, this difference is not statistically significant and sensitive to method of measurement.

Those findings are supportive of the idea that employers find it more profitable to train workers who have positively reciprocal preferences, but they are restricted to training participation in 2007: there is no relation between positive reciprocity and training participation in 2013. As unemployment dropped substantially during this period, a possible explanation is that employers do not view the provision of training as an efficient way to establish gift-exchange relationships in a tight labour market. The value of training for the worker relative to the costs for the employer is higher in a slack labour market after all. I find some support for this explanation in the data, as the relation between reciprocal attitudes and training seems stronger in occupations with relatively weak perceived labour market prospects. Interestingly, from 2009 onwards, positively reciprocal workers do not earn higher wages, while they consistently work more hours and report higher job satisfaction. This pattern is consistent with the interpretation that 
employers use other means to establish gift-exchange relations in an increasingly tight labour market.

An important limitation of this study is that I cannot distinguish between behaviour of the employer and the worker, as I do not have information about the training opportunities employers offer to their workers. Future research with data on employers' behaviour could therefore shed further light on the mechanisms. A second avenue for future research is the role of the economic environment. The evidence points at the possibility that economic circumstances influence the means employers use to build-up gift-exchange relationships. This is in the spirit of theoretical work by Dur (2009), but further empirical exploration is needed. 


\section{References}

Barrett, Alan and Philip O'Connell (2001). Does training generally work? The returns to in-company training. Industrial and Labour Relations Review, 54(3): 647-662.

Bartlett, Kenneth (2001). The Relationship between Training and Organizational Commitment: A study in the Health Care Field. Human Resource Development Quarterly, 12(4): 335-352.

Bassanini, Andrea, Alison Booth, Giorgio Brunello, Maria De Paola, and Edwin Leuven (2007). "Workplace training in Europe" In: Brunello, Garibaldi and Wasmer (eds.), Education and Training in Europe, Oxford University Press, 2007, Ch. 8 - 13.

Becker, Gary S. (1962). Investment in Human Capital: A theoretical Analysis. Journal of Political Economy, 70 (5): 9-49.

Becker, Sascha, Dolores Messer and Stefan C. Wolter (2013). A Gift is not Always a Gift: Gift Exchange in a Voucher Experiment. Economica, 80(318), 345-371.

Benjamin, Akinyemi (2012). Human Resource Development Climate as a Predictor of Citizenship Behaviour and Voluntary Turnover Intentions in the Banking Sector. International Business Research, 5(1): 110-119.

Centorrino, Samuele, Elodie Djemai, Astrid Hopfensitz, Manfred Milinski, Paul Seabright (2015). Honest signaling in trust interactions: smiles rated as genuine induce trust and signal higher earning opportunities. Evolution and Human Behaviour, 36(1): 8-16.

Cropanzano, Russell, and Marie S. Mitchell (2005). Social Exchange Theory: An Interdisciplinary Review. Journal of Management, 31: 874-900.

De Neys, Wim, Astrid Hopfensitz, Jean-François Bonnefon (2015). Adolescents gradually improve at detecting trustworthiness from the facial features of unknown adults. Journal of Economic Psychology, 47: 17-22.

Dietz, Daniel and Thomas Zwick (2016). The Retention Effect of Training - Portability, Visibility, and Credibility, ZEW Discussion Paper No. 16-011, Mannheim.

Dohmen, Thomas, Armin Falk, David Huffman, and Uwe Sunde (2009). Homo Reciprocans: Survey Evidence on Behavioural Outcomes. Economic Journal, 119 (536): 592-612.

Dur, Robert (2009). Gift Exchange in the Workplace: Money or Attention? Journal of the European Economic Association, 7(2-3): 550-560. 
Eisenberger, Robert, Stephen Armeli, Barbara Rexwinkel, Patrick Lynch, and Linda Rhoades (2001). Reciprocation of perceived organizational support. Journal of Applied Psychology, 86 (1): 42-51.

Englmaier, Florian, Thomas Kolaska, and Stephen Leider (2016). Reciprocity in Organizations- Evidence from the WERS. CESifo Economic Studies, 62(3): 522-446.

Esteves-Sorenson, Constanca (2017). Gift exchange in the workplace: Addressing the conflicting evidence with a careful test. Management Science.

Falk, Armin, Anke Becker, Thomas Dohmen, David Huffman, Uwe Sunde (2016). The Preference Survey Module: A Validated Instrument for Measuring Risk, Time, and Social Preferences, IZA DP 9674.

Falk, Armin, Anke Becker, Thomas Dohmen, Benjamin Enke, Uwe Sunde, David Huffman (2018). Global evidence on Economic Preferences. Quarterly Journal of Economics, fortcoming.

Fehr, Ernst and Simon Gächter (2000). Fairness and Retaliation: The Economics of Reciprocity. Journal of Economic Perspectives, 14(3): 159-181.

Finan, Frederico, and Laura Schechter (2012). Vote-Buying and Reciprocity. Econometrica, 80(2): 863-882.

Fouarge, Didier, Trudie Schils and Andries de Grip (2013). Why Do Low-Educated Workers Invest Less in Further Training? Applied Economics, 45(18): 2587-2601.

Gerards, Ruud, Andries de Grip, and Maaike Witlox (2014). "Employability-miles" and worker employability awareness. Applied Economics, 46(9): 952-965.

George, Jennifer, and Gareth Jones (1997). Organizational Spontaneity in Context. Human Performance, 10(2): 153-170.

Gneezy, Uri and John A. List (2006). Putting Behavioural Economics to Work: Testing for Gift Exchange in Labour Markets Using Field Experiments. Econometrica, 74(5): $1365-1384$.

Golsteyn, Bart, and Hannah Schildberg-Hörisch (2017). Challenges in research on preferences and personality traits: Measurement, stability, and inference. Journal of Economic Psychology, 60:1-6.

Görlitz, Katja and Marcus Tamm (2016). The returns to voucher-financed training on wages, employment and job tasks. Economics of Education Review, 52: 51-62.

Heckman, James J. and Tim Kautz. (2012). Hard Evidence on Soft Skills. Labour Economics, 19(4): 451-464. 
Hennig-Schmidt, H., Rockenbach, B. and Sadrieh, A. (2010). In Search of Workers' Real Effort Reciprocity - A Field and a Labouratory Experiment. Journal of the European Economic Association, 8(4): 817-837.

Hidalgo, Diana, Hessel Oosterbeek, and Dinand Webbink (2016). The impact of training vouchers on low-skilled workers. Labour Economics, 31: 117-128

Kampkötter, Patrick, and Kathrin Marggraf (2015). Do Employees Reciprocate to IntraFirm Trainings? An Analysis of Absenteeism and Turnover Rates. International Journal of Human Resource Management, 26(22): 2888-2907.

Kosfeld, Michael, Susanne Neckermann, and Xiaolan Yang (2017). The effects of financial and recognition incentives across work contexts: the case of meaning. Economic Inquiry 55(1): 237-247.

Kube, Sebastian, Clemens Puppe, and Michel André Maréchal (2012). The Currency of Reciprocity - Gift-Exchange in the Workplace. American Economic Review, 102(4): 1644-1662.

Leuven, Edwin (2005). The economics of private-sector training: A review of the literature. Journal of Economic Surveys, 19(1): 91-111.

Leuven, Edwin, Hessel Oosterbeek, Randolph Sloof, and Chris van Klaveren (2005). Worker reciprocity and employer investment in training. Economica, 72(285): 137-149.

Little, Anthony, Benedict Jones, Lisa DeBruine, and Robin Dunbar (2013). Accuracy in discrimination of self-reported cooperators using static facial information. Personality and Individual Differences, 54(4): 507-512.

Mittal, Shweta, Vishal Gupta, and Manoj Motiani (2016). Relation between human resource development climate and organizational commitment: empirical study in Indian banking sector. International Journal of Indian Culture and Business Management, 12(2): 204-223.

Montizaan, Raymond, Andries de Grip and Didier Fouarge (2015). Training access, reciprocity, and expected retirement age. ROA-RM-2015/1, Maastricht University

Mullen, Torrey Rieser, Christy Kroustalis, Adam W. Meade, and Eric. A. Surface (2006). Assessing change in perceived organizational support due to training. Conference paper, Paper presented at the 21st annual meeting of the Society for Industrial/Organizational Psychology, Dallas, TX.

Nelen, Annemarie, and Andries de Grip (2009). Why do part-time workers invest less in human capital than full-timers? Labour, 23(s1): 61-83. 
Offerhaus, Judith (2013). The Type to Train? Impacts of Personality Characteristics on Further Training Participation. SOEP Papers on Multidisciplinary Panel Data Research No. 531. German Institute for Economic Research (DIW), Berlin.

Perugini, Marco, Marcello Gallucci, Fabio Presaghi, and Anna Paola Ercolani (2003). The personal norm of reciprocity. European Journal of Personality, 17 (4): 251-283.

Podsakoff, Philip M., Scott B. MacKenzie, Julie Beth Paine, and Daniel G. Bachrach (2000), Organizational citizenship behaviours: A critical review of the theoretical and empirical literature and suggestions for future research. Journal of Management, 26(3): $513-563$.

Sauermann, Jan (2015). Worker Reciprocity and the Returns to Training: Evidence from a Field Experiment. IZA Discussion Paper No. 9179.

Schwerdt, Guido, Dolores Messer, Ludger Woessmann and Stefan Wolter (2012). Labour Market Effects of Adult Training Vouchers: Evidence from a Randomized Field Experiment, Journal of Public Economics, 96 (7-8): 569-583.

Stirrat, Michael, and David Ian Perrett (2010). Valid Facial Cues to Cooperation and Trust: Male Facial Width and Trustworthiness. Psychological Science 21(3), 349-354.

Zheng, Jin Di (2017). Homo Reciprocans Revisited, Tinbergen Institute Discussion Papers 17-040/I.

Zwick, Thomas (2015) Training older employees: what is effective? International Journal of Manpower 36 (2), 135-150. 


\section{Tables}

Table 1: Descriptive statistics

\begin{tabular}{lcc|cc} 
& \multicolumn{2}{c|}{ 2008 wave } & \multicolumn{2}{c}{2014 wave } \\
\hline Observations in sample: & \multicolumn{2}{c|}{6125} & No & Yes \\
\hline \hline Participated in training: & No & Yes & 2940 & 1128 \\
& 4179 & 1946 & $(72 \%)$ & $(28 \%)$ \\
& $(68 \%)$ & $(32 \%)$ & & $74(7 \%)$ \\
& & & $204(18 \%)$ \\
Source of finance: & $255(13 \%)$ & & \\
Financed by worker & $501(26 \%)$ & & \\
Supported by employer & $1190(61 \%)$ & & \\
Financed by employer & & & \\
\hline Employer financed training, by & & & \\
generality: & $145(12 \%)$ & & \\
Firm-specific training & $444(37 \%)$ & & \\
Visible or transferable training & $591(50 \%)$ & & \\
General training & $10(1 \%)$ & & \\
Incomplete information on generality &
\end{tabular}


Table 2: Reciprocal attitudes and training participation

\begin{tabular}{|c|c|c|c|c|c|c|}
\hline \multirow{2}{*}{$\begin{array}{l}\text { Dependent variable: } \\
\text { Variables }\end{array}$} & \multicolumn{3}{|c|}{ Participated in training, 2007} & \multicolumn{3}{|c|}{ Participated in training, 2013} \\
\hline & $(1)$ & $(2)$ & (3) & $(4)$ & (5) & (6) \\
\hline Positive reciprocity: medium & $\begin{array}{l}0.035^{* *} \\
(0.017)\end{array}$ & $\begin{array}{l}0.030^{*} \\
(0.016)\end{array}$ & $\begin{array}{l}0.031^{* *} \\
(0.016)\end{array}$ & $\begin{array}{c}0.022 \\
(0.019)\end{array}$ & $\begin{array}{c}0.021 \\
(0.019)\end{array}$ & $\begin{array}{c}0.023 \\
(0.018)\end{array}$ \\
\hline Positive reciprocity: high & $\begin{array}{l}0.037 * * \\
(0.016)\end{array}$ & $\begin{array}{l}0.036 * * \\
(0.015)\end{array}$ & $\begin{array}{l}0.036 * * \\
(0.015)\end{array}$ & $\begin{array}{c}0.017 \\
(0.018)\end{array}$ & $\begin{array}{c}0.012 \\
(0.017)\end{array}$ & $\begin{array}{c}0.011 \\
(0.017)\end{array}$ \\
\hline Negative reciprocity: medium & $\begin{array}{l}-0.012 \\
(0.016)\end{array}$ & $\begin{array}{l}-0.008 \\
(0.016)\end{array}$ & $\begin{array}{l}-0.009 \\
(0.015)\end{array}$ & $\begin{array}{l}-0.006 \\
(0.019)\end{array}$ & $\begin{array}{l}-0.007 \\
(0.018)\end{array}$ & $\begin{array}{l}-0.006 \\
(0.018)\end{array}$ \\
\hline negative reciprocity: high & $\begin{array}{c}-0.056^{* * *} \\
(0.017)\end{array}$ & $\begin{array}{l}-0.024 \\
(0.016)\end{array}$ & $\begin{array}{l}-0.025 \\
(0.016)\end{array}$ & $\begin{array}{c}-0.050 * * * \\
(0.019)\end{array}$ & $\begin{array}{l}-0.020 \\
(0.019)\end{array}$ & $\begin{array}{l}-0.021 \\
(0.019)\end{array}$ \\
\hline $\begin{array}{l}\text { Demographic characteristics and } \\
\text { month of interview }\end{array}$ & yes & yes & yes & Yes & Yes & Yes \\
\hline Big-5, risk and time preferences, trust & yes & yes & yes & yes & Yes & Yes \\
\hline Education & no & yes & yes & no & yes & Yes \\
\hline Occupation & no & yes & yes & no & yes & yes \\
\hline Industry, firm size and location & no & no & yes & no & no & yes \\
\hline Observations & 5178 & 5178 & 5178 & 3429 & 3429 & 3429 \\
\hline
\end{tabular}

Method: Probit. Coefficients report average marginal effects. Robust standard errors in parentheses, $* * *$ $p<0.01,{ }^{* *} p<0.05, * p<0.1$. Columns $1-3$ regress training participation in 2007 or early 2008 on reciprocity elicited in 2005. Columns 4-6 regress training in 2013 on reciprocity elicited in 2010.

Demographic characteristics: Gender, age, age ${ }^{\wedge} 2$, tenure, tenure ${ }^{\wedge} 2$, contractual hours, temporary contract, number of children, having a partner, experienced unemployment for $>1 / 2$ year, nationality.

Education and Occupation: Dummies for education (8 cat.) and occupational status (13 cat.)

Industry, firm size and location: Dummies for industry (7 cat.), firm size (6 cat.), and location in East or West Germany. 
Table 3: Reciprocal attitudes and source of finance

Method: multinomial logit.

Training participation in 2007

Training participation in 2013

\begin{tabular}{|c|c|c|c|c|c|c|c|c|}
\hline Variables & $\begin{array}{c}\text { No training } \\
\text { participation } \\
(1) \\
\end{array}$ & $\begin{array}{c}\text { Worker } \\
\text { financed } \\
\text { training } \\
(2)\end{array}$ & $\begin{array}{c}\text { Employer } \\
\text { supported } \\
\text { training } \\
(3) \\
\end{array}$ & $\begin{array}{c}\text { Employer } \\
\text { financed } \\
\text { training } \\
\text { (4) }\end{array}$ & $\begin{array}{c}\text { No training } \\
\text { participation } \\
(5) \\
\end{array}$ & $\begin{array}{c}\text { Worker } \\
\text { financed } \\
\text { training } \\
(6) \\
\end{array}$ & $\begin{array}{c}\text { Employer } \\
\text { supported } \\
\text { training } \\
(7) \\
\end{array}$ & $\begin{array}{c}\text { Employer } \\
\text { financed } \\
\text { training } \\
(8) \\
\end{array}$ \\
\hline Positive reciprocity: medium & $\begin{array}{c}-0.041 * * \\
(0.017)\end{array}$ & $\begin{array}{c}-0.002 \\
(0.007)\end{array}$ & $\begin{array}{c}-0.001 \\
(0.010)\end{array}$ & $\begin{array}{c}0.043^{* * *} \\
(0.015)\end{array}$ & $\begin{array}{c}-0.022 \\
(0.020)\end{array}$ & $\begin{array}{c}-0.001 \\
(0.004)\end{array}$ & $\begin{array}{c}0.004 \\
(0.008)\end{array}$ & $\begin{array}{c}0.019 \\
(0.018)\end{array}$ \\
\hline Positive reciprocity: high & $\begin{array}{c}-0.037^{* *} \\
(0.016)\end{array}$ & $\begin{array}{c}-0.011 \\
(0.007)\end{array}$ & $\begin{array}{c}0.001 \\
(0.009)\end{array}$ & $\begin{array}{c}0.047^{* * *} \\
(0.014)\end{array}$ & $\begin{array}{l}-0.013 \\
(0.018)\end{array}$ & $\begin{array}{c}0.003 \\
(0.003)\end{array}$ & $\begin{array}{c}0.003 \\
(0.008)\end{array}$ & $\begin{array}{c}0.007 \\
(0.017)\end{array}$ \\
\hline Negative reciprocity: medium & $\begin{array}{c}0.017 \\
(0.016)\end{array}$ & $\begin{array}{c}0.000 \\
(0.007)\end{array}$ & $\begin{array}{c}-0.005 \\
(0.009)\end{array}$ & $\begin{array}{c}-0.012 \\
(0.014)\end{array}$ & $\begin{array}{c}0.007 \\
(0.019)\end{array}$ & $\begin{array}{l}-0.000 \\
(0.003)\end{array}$ & $\begin{array}{c}0.003 \\
(0.007)\end{array}$ & $\begin{array}{c}-0.009 \\
(0.018)\end{array}$ \\
\hline negative reciprocity: high & $\begin{array}{c}0.053^{* * *} \\
(0.017)\end{array}$ & $\begin{array}{c}0.002 \\
(0.007)\end{array}$ & $\begin{array}{c}-0.020 * * \\
(0.010)\end{array}$ & $\begin{array}{c}-0.036^{* *} \\
(0.014)\end{array}$ & $\begin{array}{c}0.042 * * \\
(0.019)\end{array}$ & $\begin{array}{c}0.002 \\
(0.003)\end{array}$ & $\begin{array}{l}-0.008 \\
(0.008)\end{array}$ & $\begin{array}{c}-0.036 * * \\
(0.018)\end{array}$ \\
\hline
\end{tabular}

Coefficients report average marginal effects from multinomial logit estimation. Robust standard errors in parentheses: $* * * p<0.01, * * p<0.05, * p<0.1$. Columns $1-4$ relate training participation in 2007 or early 2008 to reciprocity elicited in 2005 . Columns 5-7 relate training participation in 2013 to reciprocity elicited in 2010 . The estimations control for demographic characteristics and a dummy for obtaining a degree in tertiary education. Demographic characteristics include gender, age, age 2, tenure, tenure^ 2 , contractual hours, number of children, having a partner, experienced unemployment for $>1 / 2$ year, nationality. 
Table 4: Reciprocal attitudes and transferability of training

Method: multinomial logit.

\begin{tabular}{|c|c|c|c|c|c|c|}
\hline \multirow[b]{3}{*}{ Variables } & \multirow{3}{*}{$\begin{array}{c}\text { No training } \\
\text { participation }\end{array}$} & \multirow{3}{*}{$\begin{array}{c}\text { Worker } \\
\text { financed } \\
\text { training } \\
\\
(2) \\
\end{array}$} & \multirow{3}{*}{$\begin{array}{c}\text { Employer } \\
\text { supported } \\
\text { training } \\
\\
\\
(3) \\
\end{array}$} & \multirow{3}{*}{$\begin{array}{l}\text { Employer } \\
\text { financed } \\
\text { training: } \\
\text { Firm } \\
\text { specific } \\
(4) \\
\end{array}$} & \multirow{3}{*}{$\begin{array}{c}\text { Employer } \\
\text { financed } \\
\text { training: } \\
\text { Visible or } \\
\text { transferable } \\
(5) \\
\end{array}$} & \multirow{3}{*}{$\begin{array}{c}\text { Employer } \\
\text { financed } \\
\text { training: } \\
\text { General } \\
(6) \\
\end{array}$} \\
\hline & & & & & & \\
\hline & & & & & & \\
\hline \multirow[t]{2}{*}{ Positive reciprocity: medium } & $-0.041 * *$ & -0.002 & -0.001 & 0.004 & 0.014 & $0.025^{* *}$ \\
\hline & $(0.017)$ & $(0.007)$ & $(0.010)$ & $(0.005)$ & $(0.010)$ & $(0.011)$ \\
\hline \multirow[t]{2}{*}{ Positive reciprocity: high } & $-0.036 * *$ & -0.011 & 0.001 & -0.003 & $0.026 * * *$ & $0.023 * *$ \\
\hline & $(0.016)$ & $(0.007)$ & $(0.009)$ & $(0.006)$ & $(0.009)$ & $(0.011)$ \\
\hline \multirow[t]{2}{*}{ Negative reciprocity: medium } & 0.016 & 0.000 & -0.005 & 0.005 & -0.005 & -0.012 \\
\hline & $(0.016)$ & $(0.007)$ & $(0.009)$ & $(0.006)$ & $(0.009)$ & $(0.010)$ \\
\hline \multirow[t]{2}{*}{ negative reciprocity: high } & $0.053^{* * *}$ & 0.002 & $-0.020 * *$ & 0.004 & -0.014 & $-0.025^{* *}$ \\
\hline & $(0.017)$ & $(0.007)$ & $(0.010)$ & $(0.006)$ & $(0.010)$ & $(0.011)$ \\
\hline
\end{tabular}

Coefficients report average marginal effects from multinomial logit estimation. Robust standard errors in parentheses: *** $p<0.01, * * p<0.05, * p<0.1$. Columns 1-5 relate training participation in 2007 or early 2008 to reciprocity elicited in 2005. Columns 6-8 relate training participation in 2013 to reciprocity elicited in 2010. The estimations control for demographic characteristics (Gender, age, age ${ }^{\wedge}$, tenure, tenure ${ }^{\wedge} 2$, contractual hours, number of children, having a partner, experienced unemployment for $>1 / 2$ year, nationality.) and a dummy for obtaining a degree in tertiary education. 
Table 5: Reciprocal attitudes and training participation: panel sample

Method: multinomial logit.
Participated in training in 2007

$\begin{array}{cc}\begin{array}{c}\text { No training } \\ \text { participation }\end{array} & \begin{array}{c}\text { Worker } \\ \text { financed } \\ \text { or } \\ \text { employer } \\ \text { supported } \\ \text { training }\end{array}\end{array}$

Participated in training in 2013

\begin{tabular}{c|ccc}
$\begin{array}{c}\text { Employer } \\
\text { financed } \\
\text { training }\end{array}$ & $\begin{array}{c}\text { No training } \\
\text { participation }\end{array}$ & $\begin{array}{c}\text { Worker } \\
\text { financed }\end{array}$ & $\begin{array}{c}\text { Employer } \\
\text { financed } \\
\text { or } \\
\text { training }\end{array}$ \\
& & $\begin{array}{c}\text { employer } \\
\text { supported } \\
\text { training }\end{array}$ &
\end{tabular}

\begin{tabular}{lcccccc} 
Variables & $(1)$ & $(2)$ & $(3)$ & $(4)$ & $(5)$ & $(6)$ \\
\hline \hline Positive reciprocity: medium & $-0.051^{*}$ & 0.012 & 0.038 & -0.015 & -0.008 & 0.023 \\
& $(0.027)$ & $(0.019)$ & $(0.025)$ & $(0.024)$ & $(0.014)$ & $(0.023)$ \\
Positive reciprocity: high & $-0.064^{* *}$ & -0.008 & $0.072^{* * *}$ & -0.004 & 0.004 & -0.001 \\
& $(0.026)$ & $(0.018)$ & $(0.023)$ & $(0.023)$ & $(0.012)$ & $(0.022)$ \\
Negative reciprocity: medium & 0.024 & 0.010 & -0.035 & 0.009 & 0.005 & -0.014 \\
& $(0.026)$ & $(0.018)$ & $(0.023)$ & $(0.024)$ & $(0.012)$ & $(0.022)$ \\
negative reciprocity: high & 0.038 & -0.002 & -0.036 & $0.052^{* *}$ & -0.006 & $-0.046^{* *}$ \\
& $(0.027)$ & $(0.020)$ & $(0.024)$ & $(0.024)$ & $(0.013)$ & $(0.023)$ \\
\hline Observations & & 2073 & & & 2073 &
\end{tabular}

Coefficients report average marginal effects from multinomial logit estimation. Robust standard errors in parentheses: ${ }^{* * *} p<0.01, * * p<0.05, * p<0.1$. The sample in the upper (lower) panel is constrained to individuals who (do not) feel recognized by their employer. Columns 1-3 relate training participation in 2007 or early 2008 to reciprocal inclinations elicited in 2005. Columns 4-6 relate training participation in 2013 to reciprocal inclinations elicited in 2010. The estimations control for demographic characteristics and a dummy for a degree in tertiary education. Demographic characteristics include gender, age, age ${ }^{\wedge} 2$, tenure, tenure ${ }^{\wedge}$, contractual hours, number of children, having a partner, experienced unemployment for $>1 / 2$ year, nationality. 
Table 6: Reciprocal attitudes and training participation by occupational differences in perceived labour market conditions

Method: multinomial logit.

Training participation in 2007

\begin{tabular}{|c|c|c|c|c|c|c|c|c|c|c|}
\hline & $\begin{array}{c}\text { No training } \\
\text { participation }\end{array}$ & $\begin{array}{l}\text { Worker } \\
\text { financed } \\
\text { training }\end{array}$ & $\begin{array}{l}\text { Employer } \\
\text { supported } \\
\text { training }\end{array}$ & Firm specific & $\begin{array}{l}\text { Visible or } \\
\text { transferable }\end{array}$ & General & $\begin{array}{c}\text { No training } \\
\text { participation }\end{array}$ & $\begin{array}{c}\text { Worker } \\
\text { financed } \\
\text { training }\end{array}$ & $\begin{array}{l}\text { Employer } \\
\text { supported } \\
\text { training }\end{array}$ & $\begin{array}{c}\text { Employer } \\
\text { financed } \\
\text { training }\end{array}$ \\
\hline Sample: & \multicolumn{10}{|c|}{ Occupations with relatively tight labor market } \\
\hline Variables & (1) & $(2)$ & (3) & (4) & $(5)$ & (6) & (7) & (8) & (9) & (10) \\
\hline Positive reciprocity: medium & $\begin{array}{l}-0.015 \\
(0.024)\end{array}$ & $\begin{array}{c}0.002 \\
(0.010)\end{array}$ & $\begin{array}{l}-0.003 \\
(0.014)\end{array}$ & $\begin{array}{l}-0.001 \\
(0.008)\end{array}$ & $\begin{array}{c}0.019 \\
(0.014)\end{array}$ & $\begin{array}{l}-0.002 \\
(0.016)\end{array}$ & $\begin{array}{c}0.005 \\
(0.028)\end{array}$ & $\begin{array}{l}-0.004 \\
(0.012)\end{array}$ & $\begin{array}{c}0.012 \\
(0.016)\end{array}$ & $\begin{array}{l}-0.013 \\
(0.026)\end{array}$ \\
\hline Positive reciprocity: high & $\begin{array}{l}-0.028 \\
(0.023)\end{array}$ & $\begin{array}{c}0.005 \\
(0.010)\end{array}$ & $\begin{array}{l}-0.009 \\
(0.013)\end{array}$ & $\begin{array}{l}-0.009 \\
(0.008)\end{array}$ & $\begin{array}{c}0.035^{* * *} \\
(0.013)\end{array}$ & $\begin{array}{c}0.006 \\
(0.015)\end{array}$ & $\begin{array}{l}-0.022 \\
(0.026)\end{array}$ & $\begin{array}{c}0.015 \\
(0.009)\end{array}$ & $\begin{array}{c}0.013 \\
(0.015)\end{array}$ & $\begin{array}{l}-0.006 \\
(0.024)\end{array}$ \\
\hline Observations & \multicolumn{6}{|c|}{2520} & \multicolumn{4}{|c|}{1646} \\
\hline
\end{tabular}

Sample:

\begin{tabular}{|c|c|c|c|c|c|c|c|c|c|c|}
\hline \multirow{2}{*}{$\begin{array}{l}\text { Sample: } \\
\text { Positive reciprocity: medium }\end{array}$} & \multicolumn{10}{|c|}{ Occupations with relatively slack labor market } \\
\hline & $\begin{array}{c}-0.066 * * * \\
(0.023)\end{array}$ & $\begin{array}{c}-0.004 \\
(0.010)\end{array}$ & $\begin{array}{l}-0.002 \\
(0.014)\end{array}$ & $\begin{array}{c}0.009 \\
(0.007)\end{array}$ & $\begin{array}{c}0.011 \\
(0.014)\end{array}$ & $\begin{array}{c}0.052^{* * *} \\
(0.016)\end{array}$ & $\begin{array}{l}-0.044^{*} \\
(0.025)\end{array}$ & $\begin{array}{l}-0.001 \\
(0.005)\end{array}$ & $\begin{array}{l}-0.002 \\
(0.010)\end{array}$ & $\begin{array}{l}0.047^{*} \\
(0.024)\end{array}$ \\
\hline Positive reciprocity: high & $\begin{array}{c}-0.047^{* *} \\
(0.022) \\
\end{array}$ & $\begin{array}{c}-0.024^{* *} \\
(0.010) \\
\end{array}$ & $\begin{array}{c}0.008 \\
(0.013) \\
\end{array}$ & $\begin{array}{c}0.001 \\
(0.008) \\
\end{array}$ & $\begin{array}{c}0.020 \\
(0.013) \\
\end{array}$ & $\begin{array}{c}0.041^{* * *} \\
(0.016) \\
\end{array}$ & $\begin{array}{l}-0.003 \\
(0.025) \\
\end{array}$ & $\begin{array}{c}-0.006 \\
(0.006) \\
\end{array}$ & $\begin{array}{l}-0.007 \\
(0.009) \\
\end{array}$ & $\begin{array}{c}0.016 \\
(0.023) \\
\end{array}$ \\
\hline Observations & \multicolumn{6}{|c|}{2809} & \multicolumn{4}{|c|}{1843} \\
\hline
\end{tabular}

Coefficients report average marginal effects from multinomial logit estimation. Robust standard errors in parentheses: $* * * p<0.01, * * p<0.05, * p<0.1$. The sample in the upper (lower) panel is constrained to individuals who work in an occupation where workers consider it easy (hard) on average to find a comparable job. Columns 1-6 relate training participation in 2007 or early 2008 to

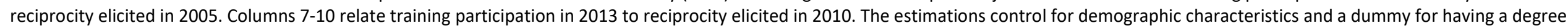
in tertiary education. Demographic characteristics include gender, age, age^2, tenure, tenure $\mathrm{e}^{\wedge}$, contractual labour hours and education.

Training participation in 2013

Occupations with relatively slack labor market 


\section{Appendix}

Table A1: Alternative definition of general training

Method: multinomial logit.

\begin{tabular}{|c|c|c|c|c|c|}
\hline Variables & $\begin{array}{l}\text { No training } \\
\text { participation }\end{array}$ & $\begin{array}{l}\text { Worker } \\
\text { financed } \\
\text { training }\end{array}$ & $\begin{array}{l}\text { Employer } \\
\text { supported } \\
\text { training }\end{array}$ & $\begin{array}{c}\text { Employer } \\
\text { financed } \\
\text { training: } \\
\text { Provided by } \\
\text { company or } \\
\text { other } \\
\text { institution } \\
(4) \\
\end{array}$ & $\begin{array}{l}\text { Employer financed } \\
\text { training: } \\
\text { Provided by formal } \\
\text { educational } \\
\text { institution or } \\
\text { professional } \\
\text { organization } \\
\text { (5) } \\
\end{array}$ \\
\hline \multirow[t]{2}{*}{ Positive reciprocity: medium } & $-0.041 * *$ & -0.002 & -0.001 & $0.026^{* *}$ & $0.018^{* *}$ \\
\hline & $(0.017)$ & $(0.007)$ & $(0.010)$ & $(0.013)$ & $(0.008)$ \\
\hline \multirow[t]{2}{*}{ Positive reciprocity: high } & $-0.037 * *$ & -0.011 & 0.001 & 0.020 & $0.027^{* * *}$ \\
\hline & $(0.016)$ & $(0.007)$ & $(0.009)$ & $(0.013)$ & $(0.008)$ \\
\hline \multirow[t]{2}{*}{ Negative reciprocity: medium } & 0.016 & 0.000 & -0.005 & 0.000 & -0.011 \\
\hline & $(0.016)$ & $(0.007)$ & $(0.009)$ & $(0.012)$ & $(0.008)$ \\
\hline \multirow[t]{2}{*}{ negative reciprocity: high } & $0.053 * * *$ & 0.002 & $-0.020 * *$ & -0.021 & $-0.014 *$ \\
\hline & $(0.017)$ & $(0.007)$ & $(0.010)$ & $(0.013)$ & $(0.008)$ \\
\hline \multicolumn{3}{|l|}{ Observations } & 5340 & & \\
\hline
\end{tabular}


Table A2: Reciprocal attitudes and training participation correcting for previous training participation

Method: multinomial logit.

\begin{tabular}{|c|c|c|c|c|c|c|c|c|c|c|}
\hline Variables & $\begin{array}{c}\text { No training } \\
\text { participation }\end{array}$ & $\begin{array}{l}\text { Worker } \\
\text { financed } \\
\text { training }\end{array}$ & $\begin{array}{l}\text { Employer } \\
\text { supported } \\
\text { training }\end{array}$ & $\begin{array}{c}\text { Employer } \\
\text { financed } \\
\text { training: } \\
\text { Firm } \\
\text { specific } \\
(4) \\
\end{array}$ & $\begin{array}{c}\text { Employer } \\
\text { financed } \\
\text { training: } \\
\text { Visible or } \\
\text { transferable } \\
(5) \\
\end{array}$ & $\begin{array}{c}\text { Employer } \\
\text { financed } \\
\text { training: } \\
\text { Transferable } \\
\text { (6) }\end{array}$ & $\begin{array}{l}\text { No training } \\
\text { participation }\end{array}$ & $\begin{array}{c}\text { Worker } \\
\text { financed } \\
\text { training }\end{array}$ & $\begin{array}{l}\text { Employer } \\
\text { supported } \\
\text { training }\end{array}$ & $\begin{array}{c}\text { Employer } \\
\text { financed } \\
\text { training }\end{array}$ \\
\hline Positive reciprocity: medium & $\begin{array}{c}-0.040 * * \\
(0.016)\end{array}$ & $\begin{array}{l}-0.005 \\
(0.007)\end{array}$ & $\begin{array}{l}-0.002 \\
(0.010)\end{array}$ & $\begin{array}{c}0.004 \\
(0.005)\end{array}$ & $\begin{array}{c}0.014 \\
(0.010)\end{array}$ & $\begin{array}{c}0.028 * * \\
(0.011)\end{array}$ & $\begin{array}{l}-0.004 \\
(0.020)\end{array}$ & $\begin{array}{l}-0.007 \\
(0.007)\end{array}$ & $\begin{array}{c}0.002 \\
(0.010)\end{array}$ & $\begin{array}{c}0.009 \\
(0.019)\end{array}$ \\
\hline Positive reciprocity: high & $\begin{array}{c}-0.030 * * \\
(0.015)\end{array}$ & $\begin{array}{c}-0.011^{*} \\
(0.007)\end{array}$ & $\begin{array}{l}-0.003 \\
(0.009)\end{array}$ & $\begin{array}{l}-0.004 \\
(0.006)\end{array}$ & $\begin{array}{c}0.027^{* * *} \\
(0.009)\end{array}$ & $\begin{array}{c}0.021 * * \\
(0.011)\end{array}$ & $\begin{array}{l}-0.004 \\
(0.019)\end{array}$ & $\begin{array}{c}0.000 \\
(0.006)\end{array}$ & $\begin{array}{c}0.004 \\
(0.010)\end{array}$ & $\begin{array}{l}-0.001 \\
(0.018)\end{array}$ \\
\hline Negative reciprocity: medium & $\begin{array}{c}0.016 \\
(0.015)\end{array}$ & $\begin{array}{l}-0.000 \\
(0.007)\end{array}$ & $\begin{array}{l}-0.005 \\
(0.009)\end{array}$ & $\begin{array}{c}0.006 \\
(0.006)\end{array}$ & $\begin{array}{l}-0.005 \\
(0.009)\end{array}$ & $\begin{array}{l}-0.011 \\
(0.010)\end{array}$ & $\begin{array}{l}-0.011 \\
(0.020)\end{array}$ & $\begin{array}{c}0.005 \\
(0.006)\end{array}$ & $\begin{array}{c}0.005 \\
(0.009)\end{array}$ & $\begin{array}{c}0.001 \\
(0.018)\end{array}$ \\
\hline Negative reciprocity: high & $\begin{array}{c}0.045^{* * *} \\
(0.016)\end{array}$ & $\begin{array}{c}0.002 \\
(0.007) \\
\end{array}$ & $\begin{array}{c}-0.021 * * \\
(0.010)\end{array}$ & $\begin{array}{c}0.006 \\
(0.006) \\
\end{array}$ & $\begin{array}{l}-0.013 \\
(0.010) \\
\end{array}$ & $\begin{array}{c}-0.018^{*} \\
(0.011) \\
\end{array}$ & $\begin{array}{c}0.024 \\
(0.020) \\
\end{array}$ & $\begin{array}{c}0.011 \\
(0.007) \\
\end{array}$ & $\begin{array}{l}-0.004 \\
(0.010) \\
\end{array}$ & $\begin{array}{l}-0.031 \\
(0.019) \\
\end{array}$ \\
\hline
\end{tabular}

Coefficients report average marginal effects from multinomial logit estimation. Robust standard errors in parentheses: $* * * p<0.01, * * p<0.05, * p<0.1$. Columns $1-6$ relate training participation in 2007 or early 2008 to reciprocity elicited in 2005 . Columns 7-10 relate training participation in 2013 to reciprocity elicited in 2010. The estimations control for demographic characteristics, a dummy for obtaining a degree in tertiary education, and previous training participation. Demographic characteristics include gender, age, age ${ }^{\wedge}$, tenure, tenure 2 , contractual hours, number of children, having a partner, experienced unemployment for $>1 / 2$ year, nationality.

\section{Training participation in 2013}

Training participation in 2007 
Table A3: Reciprocal attitudes and training participation by age category

Method: multinomial logit.
Training participation in 2007
Training participation in 2013

\begin{tabular}{cccccc} 
No training & $\begin{array}{c}\text { Worker } \\
\text { participation } \\
\text { financed or } \\
\text { employer } \\
\text { supported } \\
\text { training }\end{array}$ & $\begin{array}{c}\text { Employer } \\
\text { financed } \\
\text { training }\end{array}$ & $\begin{array}{c}\text { No training } \\
\text { participation }\end{array}$ & $\begin{array}{c}\text { Worker } \\
\text { financed or } \\
\text { employer } \\
\text { supported } \\
\text { training }\end{array}$ & $\begin{array}{c}\text { Employer } \\
\text { financed } \\
\text { training }\end{array}$ \\
\hline \hline
\end{tabular}

Sample:

Age $<40$

\begin{tabular}{lccc|ccc}
\hline \hline Variables & $(1)$ & $(2)$ & $(3)$ & $(4)$ & $(5)$ & $(6)$ \\
\hline \hline Positive reciprocity: medium & -0.014 & -0.016 & 0.029 & -0.060 & $0.053^{* *}$ & 0.007 \\
& $(0.032)$ & $(0.023)$ & $(0.028)$ & $(0.044)$ & $(0.026)$ & $(0.041)$ \\
Positive reciprocity: high & -0.031 & -0.027 & $0.058^{* *}$ & -0.053 & 0.024 & 0.029 \\
& $(0.030)$ & $(0.022)$ & $(0.026)$ & $(0.041)$ & $(0.025)$ & $(0.038)$ \\
\hline Observations & & 1553 & & 716 \\
\hline \hline
\end{tabular}

Sample:

$40 \leq$ Age $<50$

\begin{tabular}{lccc|ccc}
\hline \hline Positive reciprocity: medium & -0.034 & -0.020 & $0.054^{* *}$ & -0.041 & 0.001 & 0.040 \\
& $(0.027)$ & $(0.019)$ & $(0.023)$ & $(0.034)$ & $(0.020)$ & $(0.032)$ \\
Positive reciprocity: high & -0.028 & -0.013 & $0.040^{*}$ & -0.002 & 0.027 & -0.025 \\
& $(0.026)$ & $(0.018)$ & $(0.023)$ & $(0.033)$ & $(0.017)$ & $(0.032)$ \\
\hline Observations & & & & 1063 \\
\hline \hline
\end{tabular}

Sample:

Age $\geq 50$

\begin{tabular}{lccc|cccc}
\hline \hline Positive reciprocity: medium & $-0.070^{* *}$ & $0.034^{*}$ & 0.036 & 0.007 & -0.010 & 0.004 \\
& $(0.028)$ & $(0.019)$ & $(0.025)$ & $(0.029)$ & $(0.016)$ & $(0.027)$ \\
Positive reciprocity: high & $-0.047^{*}$ & 0.016 & 0.031 & 0.000 & -0.017 & 0.017 \\
& $(0.027)$ & $(0.018)$ & $(0.024)$ & $(0.027)$ & $(0.015)$ & $(0.025)$ \\
\hline Observations & & & & 1505 & 1503 \\
\hline \hline
\end{tabular}

Coefficients report average marginal effects from multinomial logit estimation. Robust standard errors in parentheses: *** $p<0.01, * * p<0.05, * p<0.1$. Columns 1-3 relate training participation in 2007 or early 2008 to reciprocal inclinations elicited in 2005. Columns 4-6 relate training participation in 2013 to reciprocal inclinations elicited in 2010. The estimations control for demographic characteristics and a dummy for a degree in tertiary education. Demographic characteristics include gender, age, $\operatorname{age}^{\wedge} 2$, tenure, tenure ${ }^{\wedge} 2$, contractual hours, number of children, having a partner, experienced unemployment for $>1 / 2$ year, nationality. 
Table A4: Reciprocal attitudes and actual hours worked, job satisfaction, and income in different survey years

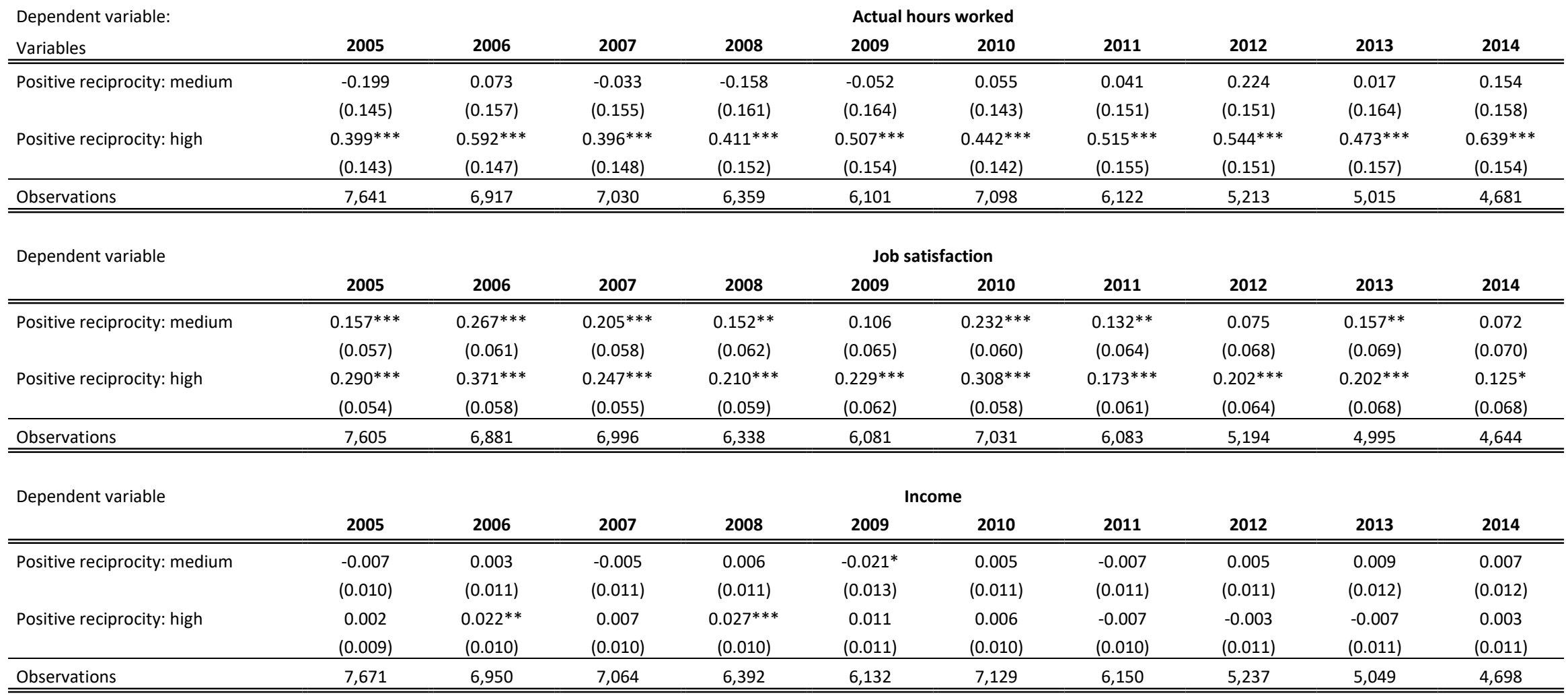

Each column reports ols-estimations from a different survey year. Robust standard errors in parentheses: $* * * p<0.01, * * p<0.05, * p<0.1$. Columns $1-5$ relate outcomes to reciprocal inclinations elicited in 2005. Columns 6-10 relate outcomes to reciprocal inclinations elicited in 2010. The estimations control for demographic characteristics gender, age, age 2 tenure, tenure ${ }^{\wedge} 2$, full-time work experience, full-time work experience ${ }^{\wedge} 2$, part-time work experience, part-time work experience 2 , contractual hours, contractual hours ${ }^{\wedge} 2$, number of children, having a partner, experienced unemployment for $>1 / 2$ year, nationality, education, occupation, size of firm, industry, state of residence. 